\title{
EVIDENCE OF HUMAN NON- $\alpha$-GALACTOSYL ANTIBODIES INVOLVED IN THE HYPERACUTE REJECTION OF PIG LUNGS AND THEIR REMOVAL BY PIG ORGAN PERFUSION
}

Paolo Macchiarini, $\mathrm{MD}, \mathrm{PhD}^{\mathrm{a}}$

Rafael Oriol, $\mathrm{MD}^{\mathrm{b}}$

Agnès Azimzadeh, $\mathrm{PhD}^{\mathrm{c}}$

Vincent de Montpreville, $\mathrm{MD}^{\mathrm{a}}$

Robert Rieben, $\mathrm{PhD}^{\mathrm{d}}$

Nicolai Bovin, $\mathrm{PhD}^{\mathrm{e}}$

Michel Mazmanian, MD $^{\mathrm{a}}$

Philippe Dartevelle, MD
Background: Human natural xenoantibodies represent a major hurdle to the clinical application of pig lungs in transplantation by initiating hyperacute rejection within minutes to hours. Objective: The object was to compare pig organ perfusion and specific depletion of anti- $\alpha$-galactosyl xenoantibodies for prevention of hyperacute rejection in the pig to human lung combination. Methods: Large White pig (20-25 kg) left lungs were removed and continuously ventilated and reperfused ex vivo either with (1) whole human blood previously perfused in situ through pig right lung (group I), liver (group II), or spleen (group III) or with (2) human plasma in vitro immunoabsorbed on columns containing $\alpha$ galactosyl disaccharide (Gal- $\alpha-(1-3)$ Gal- $\beta-\left(\mathrm{CH}_{2}\right)_{3} \mathrm{NH}_{2} ; \mathrm{B}$ disaccharide) (group IV). Each study group included 6 animals. Results: The in situ and in vitro preperfusions depleted anti- $\alpha$-galactosyl xenoantibodies and all in situ perfused pig organs showed histologic signs of hyperacute rejection. After the ex vivo reperfusion, group I xenografts had a significantly $(P<.001)$ longer functional and histologic survival than did xenografts in groups II, III, and IV. Human blood reperfusing group I xenografts had a significantly $(P<0.05)$ lower $(1)$ decline of clotting factors and total circulating immunoglobulins, (2) total and membrane attack complex $(\mathrm{C} 5 \mathrm{~b}, 6,7,8,9)$ complement activation, and (3) hemolysis. By Western blot analysis, the in situ lung preperfusion removed antibodies against non- $\alpha$-galactosyl proteins of low molecular weight that were not eliminated by the $\alpha$-galactosyl column. Conclusions: Results demonstrate that specific depletion of anti- $\alpha$-galactosyl antibodies alone incompletely protects pig lungs from hyperacute rejection. It is speculated that the more complete prevention of this rejection afforded by pig lung preperfusion relates to the removal of other, non- $\alpha$-galactosyl antibodies. (J Thorac Cardiovasc Surg 1998;116:831-43)
From the Department of Thoracic and Vascular Surgery and Heart-Lung Transplantation and Experimental Surgical Laboratory, Hôpital Marie-Lannelongue, Le Plessis Robinson, Paris-Sud Universitya; INSERM U. 178 Villejuif ${ }^{\text {; }}$ Laboratory of Experimental Surgery, Fondation Transplantation, Strasbourg, France ${ }^{c}$; Department of Cardiology, Bern University Hospital, Switzerland ${ }^{\text {d. Shemyakin and }}$ Ovchinnikov Institute of Bioorganic Chemistry, Russian Academy of Sciences, Moscow, Russian Federation. ${ }^{\mathrm{e}}$

Supported by the Xenotransplantation project within the European Community program DGXII Biotechnology (shared cost BI04CT97-2242 and concerted action 3026PL950004) and Fondation Transplantation.

Read at the Seventy-eighth Annual Meeting of The American Association for Thoracic Surgery, Boston, Mass, May 3-6, 1998.

Received for publication May 8, 1998; revisions requested June 10, 1998; revisions received July 9, 1998; accepted for publication July 9, 1998.

Address for reprints: Paolo Macchiarini, $\mathrm{MD}, \mathrm{PhD}$, Department of Thoracic and Vascular Surgery and Heart-Lung Transplantation, Hôpital Marie-Lannelongue (Paris-Sud University), 133, Avenue de la Resistance, 92350 Le Plessis Robinson, France.

Copyright (C) 1998 by Mosby, Inc.

$0022-5223 / 98 \$ 5.00+0 \quad \mathbf{1 2 / 6 / 9 3 0 9 3}$
$T_{i}$ he clinical use of pig lungs for human allodonations is limited by the hyperacute rejection, ${ }^{1}$ the hallmark of xenograft dysfunction in such discordant transplants as the pig to human combination. This process results from the binding of human natural antibodies to the porcine endothelium, which in turn activates the complement cascade, inducing endothelial injury, pulmonary edema, thrombosis of the pulmonary microcirculation, increase in pulmonary vascular resistance (PVR), and loss of xenograft function within 1 to 2 hours of revascularization. ${ }^{2-4}$

With the increasing understanding of its pathophysiology, 5,6 2 basic strategies to prevent lung hyperacute rejection have emerged: (1) depletion of human natural xenoantibodies $^{2,7}$ and (2) inhibition of complement activation. ${ }^{4,8}$ Whereas experiments with pigs transgenic for complement regulatory proteins $\mathrm{s}^{4,8}$ or selective pharmacologic blockage of complement ${ }^{2,9}$ demonstrated incom- 


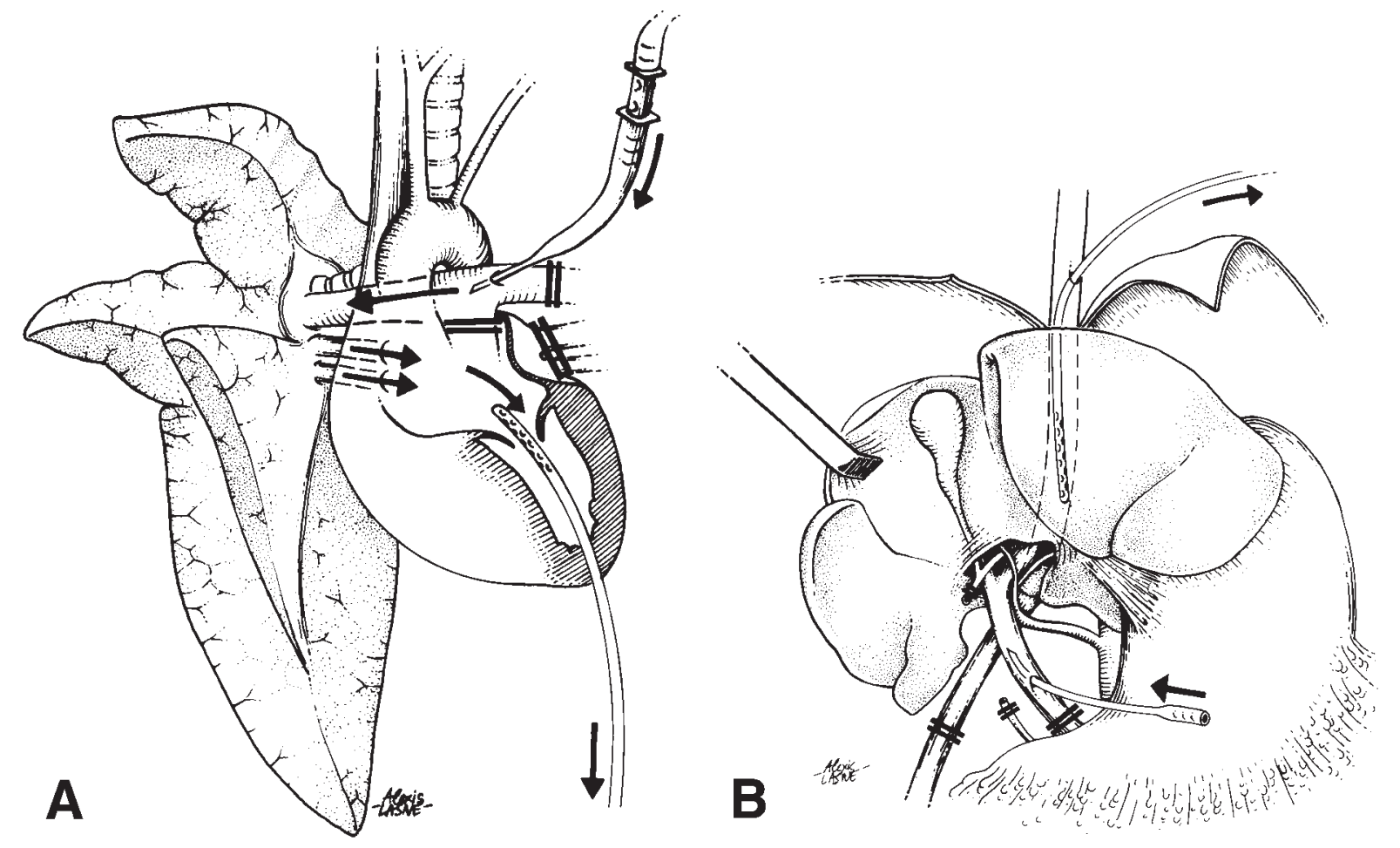

Fig 1. Surgical isolation of pig donor right lung (A) and liver (B).

plete physiologic protection, Daggett and associates ${ }^{7}$ provided recent evidence that pretransplantation pig lung perfusion prevented pig to primate pulmonary xenograft rejection. Unfortunately, the exact mechanisms responsible for this effect were not elucidated. To test the hypothesis that the anti- $\alpha$-galactosyl (anti- $\alpha$-Gal) xenoantibodies may not be the only human molecules triggering pig lung hyperacute rejection, ${ }^{10}$ human blood was immunoabsorbed either through pig donor organs (lung, liver, spleen) or $\alpha$-galactosyl ( $\alpha$-Gal) columns and subsequently used to perfuse an ex vivo pig lung working model.

\section{Materials and methods}

Animals and study design. Large White outbred pigs weighing between 20 and $30 \mathrm{~kg}$ served as lung donors. All animals received care in compliance with the "Principles of Laboratory Animal Care" formulated by the National Society for Medical Research and the "Guide for the Care and Use of Laboratory Animals" formulated by the National Academy of Sciences (NIH publication no 85-23, revised 1985). Human blood was obtained from informed patients (Claude Huriet Law, No 88-1138, 20 December 1988 [French law]) undergoing therapeutic phlebotomies for hemochromatosis, collected at the Blood Banks of the West Île-de-France Public Interest Group, and screened for viral-transmitted diseases. Each blood unit (approximately $400 \mathrm{~mL}$ ) was anticoagulated with $1.2 \mathrm{U} / \mathrm{mL}$ heparin and used within 30 days.
Four experimental groups were randomly studied. The human blood was absorbed in situ through isolated pig donor right lung (group I), liver (group II), or spleen (group III), or was absorbed in vitro (human plasma) through an $\alpha$-Gal column (group IV). The collected or reconstituted human blood was then used to perfuse ex vivo the left lungs taken from the same pig donors until the onset of rejection. Each study group included 6 animals. Blood samples were taken at baseline and after 10, 30, 60, 90, 120, and 180 minutes of reperfusion and were subsequently stored in aliquots at $-80^{\circ} \mathrm{C}$ until use.

In situ pig organ perfusion. Animals were medicated before the experiment with intramuscular ketamine hydrochloride $(25 \mathrm{mg} / \mathrm{kg})$ and atropine sulfate $(1 \mathrm{mg} / \mathrm{kg})$ and were anesthetized with intravenous sodium pentobarbital (25 $\mathrm{mg} / \mathrm{kg}$ ). After orotracheal intubation, anesthesia was maintained with inhaled halothane and the animals received mechanical ventilation (Labaz Inc Ventilator, Chemin CamiSaliè, Pau, France) with an equal gas mixture of oxygen and protoxide. Ear venous catheters were placed for infusion of crystalloid solutions; adequacy of ventilation and adequacy of oxygenation were assessed by arterial blood gas analysis and pulse oximetry. After completion of a median sternotomy and upper laparotomy, the abdominal viscera were lifted away from the diaphragm to avoid compression of the lower lung lobes and the anterior pericardium was opened and suspended. The isolated organs were perfused with an infusing arterial cannula (William Harvey, CR Bard, Inc, Billerica, Mass), with a single passage of human blood (initial total vol- 
ume approximately $400 \mathrm{~mL}$ ). A venting cannula (William Harvey) drained the passed human blood into plastic bags (Maco Pharma, Tours, France).

In group I a single circular purse-string suture of 4-0 polypropylene (Prolene; Ethicon, Inc, Somerville, NJ) was placed in the pulmonary artery trunk for insertion of a $14 \mathrm{~F}$ arterial cannula; a second suture with several polytetrafluoroethylene (Teflon) felt pledgets was placed on the tip of the left ventricle for insertion of a $20 \mathrm{~F}$ venting atrioventricular cannula. After systemic heparinization $(3 \mathrm{mg} / \mathrm{kg})$ and topical electrically induced cardiac arrest, the origin of the ascending aorta and pulmonary trunk were crossclamped and both lungs preserved by Euro-Collins solution (ECS; total volume 65 $\mathrm{mL} / \mathrm{kg}$ at $4^{\circ} \mathrm{C}$ at a perfusion pressure of $80 \mathrm{~mm} \mathrm{Hg}$ ) infused and drained through the arterial and venting cannulas; the right atrium was opened to decompress the right heart chambers. After completion of the perfusate, the right lungs were isolated by (1) crossclamping the origin of the left pulmonary artery and left atrium beyond the orifices of the left pulmonary veins, (2) ligating the infracardiac lobe vessels, and (3) clamping (in inflation) the left main bronchus after development of the posterior pericardium. The right lungs were then perfused (perfusion pressure $80 \mathrm{~mm} \mathrm{Hg}$ ) with a human blood unit with the arterial and venting cannulas (Fig 1, A).

In group II the infracardiac pleural space was opened and the inferior vena cava (IVC) was dissected from its entry into the right atrium up to its suprahepatic veins origin after perpendicular and midline division of the diaphragmatic muscle. The hepatic artery and choledochal duct were then ligated at the hepatic ligament above the second portion of duodenum to allow exposure of the portal vein, which was subsequently cannulated at its origin with a $21 \mathrm{~F}$ arterial cannula inserted through a circular purse-string 4-0 Prolene suture. The right hepatic lobes (medial, lateral, and caudal) were then lifted on the left and the right diaphragmatic crus was opened to expose the infrahepatic IVC, which was encircled with a tourniquet. A $14 \mathrm{~F}$ venting cannula was then inserted through a purse-string 4-0 Prolene suture into the suprahepatic IVC. After systemic heparinization $(3 \mathrm{mg} / \mathrm{kg})$ and topical electrically induced cardiac arrest, the lungs were flushed with ECS as for group I animals. Total vascular liver exclusion was then obtained by ligating the suprahepatic IVC at its entrance into the right atrium and the origin of the infrahepatic IVC, and by division of the coronary and triangular ligaments. After ligation of the origin of the portal vein, the liver was flushed with $2 \mathrm{~L} 4^{\circ} \mathrm{C} \mathrm{ECS} \mathrm{(per-}$ fusion pressure $100 \mathrm{~mm} \mathrm{Hg}$ ) through the previously placed cannulas. Thereafter the liver was perfused with the human blood unit through the same closed circuit (Fig 1,B).

In group III animals the splenic artery and vein were dissected and cannulated with a $12 \mathrm{~F}$ arterial cannula and a $14 \mathrm{~F}$ venting cannula placed through 2 purse-string circular 5-0 Prolene sutures. After systemic heparinization $(3 \mathrm{mg} / \mathrm{kg})$ and topical electrically induced cardiac arrest, both lungs were flushed with ECS as described previously. The spleens were isolated by ligating the splenic artery and veins beyond their cannulas and were perfused with $2 \mathrm{~L} 4^{\circ} \mathrm{C}$ ECS first and then with human blood.
In vitro $\alpha$-Gal immunoabsorption of human plasma. Spacered Gal $\alpha(1-3) \mathrm{Gal}$ disaccharide haptens were produced by chemical synthesis ${ }^{11}$ and covalently coupled to a flexible, hydrophilic polymer (poly $N$-hydroxyethylacrylamide; PAA) of approximately $35 \mathrm{kDa}^{12,13}$ The PAA- $\alpha$-Gal conjugates were covalently coupled to Sepharose 6 FF (Pharmacia Biotech, Export GmbH, Vienna, Austria). The resulting $\alpha-\mathrm{Gal}$ immunoabsorbent is mechanically and chemically stable and can be sterilized with formaldehyde.

Chromatographic columns $2.5 \mathrm{~cm}$ in diameter (Econo column; BioRad, Richmond, Calif) were packed with approximately $50 \mathrm{~mL}$ of the $\alpha$-Gal immunoabsorbent and connected to a peristaltic pump at a flow rate of about $4 \mathrm{~mL} / \mathrm{min}$. The columns were rinsed with $250 \mathrm{~mL}$ phosphate-buffered saline solution (PBS), $\mathrm{pH} 7.4$, and subsequently with $250 \mathrm{~mL} \mathrm{5 \%}$ human serum albumin (albumin SRK; Central Laboratory, Swiss Red Cross, Bern, Switzerland). The pump was then turned off and the column was incubated with the human serum albumin solution for about 2 hours at room temperature. After rinsing with another $100 \mathrm{~mL}$ 5\% human serum albumin, the column was immediately used for antibody absorption. Each human blood unit was separated into formed elements and plasma by centrifugation for 15 minutes at $3000 \mathrm{~g}$. The blood cells were washed with PBS (15 minutes, $3000 \mathrm{~g}$ ) to remove remaining plasma. The plasma itself (approximately $220 \mathrm{~mL}$ ) was absorbed on the $\alpha$-Gal column (group IV). Absorbed plasma and washed blood cells were

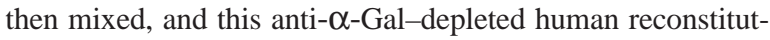
ed whole blood was used for the ex vivo pig left lung perfusion experiments. After absorption the column was regenerated as follows: rinsing with $400 \mathrm{~mL}$ PBS, acid elution of bound antibodies with $300 \mathrm{~mL} 0.1 \mathrm{~mol} / \mathrm{L}$ glycine hydrochloride, $\mathrm{pH}$ 2.3 , rinsing again with $400 \mathrm{~mL}$ PBS and subsequently with $200 \mathrm{~mL} \mathrm{2 \%}$ formaldehyde solution in PBS for sterilization, and storage of immunoabsorption material in the formaldehyde solution until further use.

Harvest technique. On completion of the in situ pig organ or in vitro column perfusion, pig left lungs were removed. Care was taken to have the maximum length of the left pulmonary artery and main bronchus and a large cuff of left atrium incorporating the 3 to 4 left pulmonary veins and the venous return from the infracardiac lobe of the right lung. A 4-0 Prolene purse-string suture was placed on the free cuff walls of the left atrium. The grafts were then placed inflated in 2 sterile plastic bags containing cold $\left(4^{\circ} \mathrm{C}\right) \mathrm{ECS}$.

Before the ex vivo experiments, $\mathrm{a}^{3} / 8$-inch straight tube connector (Dideco Inc, Mirandola, Italy) was placed in the left pulmonary artery for pulmonary artery inflow, another was placed in the left main bronchus for mechanical ventilation, and another was placed in the cuff of the left atrium to passively drain pulmonary vein blood outflow. Ligatures were then tied around the cannulas.

Ex vivo pig-to-human lung xenograft model. The ex vivo lung perfusion and ventilation model was used as described previously. ${ }^{3}$ In brief, left lungs suspended by the left main bronchus connectors in a thermostatically controlled, humidified chamber were continuously ventilated with room air 
(inspired oxygen fraction 0.21 ) by a mechanical ventilator (Siemens-Elema, Solna, Sweden) at a tidal volume of $200 \mathrm{~mL}$ at 20 breaths/min with $5 \mathrm{~cm} \mathrm{H}_{2} \mathrm{O}$ positive end-expiratory pressure and perfused with autogenic undiluted pig blood for the first 30 minutes in all groups to obtain adequate stabilization. Before reperfusion with human blood, pig lungs were flushed with $1.5 \mathrm{~L}$ saline solution to avoid any hemolysis. Next, lungs were continuously ventilated with a $75 \%$ nitrogen, $20 \%$ oxygen, and $5 \%$ carbon dioxide gas mixture and perfused through the inflow and outflow connectors attached to the bloodprimed perfusion circuit through silicone tubing (Bentley ByPass 70-tubing, Bentley Laboratories, Inc, Irvine, Calif). Venous blood return was collected through the outflow cannula into the oxygenator cardiotomy reservoir, continuously deoxygenated (93\% nitrogen, 5\% carbon dioxide, and 2\% oxygen) with a neonatal oxygenating system (Polystan Safe Micro; Polystan, Copenhagen, Denmark), and returned to the left pulmonary artery through a roller pump (Ismatec mod; Bioblock, Strasbourg, France) at a flow rate of $100 \mathrm{~mL} / \mathrm{min}$. The residual human blood volume after this preperfusion was approximately $300 \mathrm{~mL}$. The total initial volume of heparinized $(0.15 \mathrm{~mL} / \mathrm{kg})$ blood perfusing the ex vivo circuit was limited to $200 \mathrm{~mL}$ blood, and further blood was added thereafter. A heater (HAAKE FK/F4391; Gebruder Haake GmbH, Berlin, Germany) warmed the humidified chamber and blood to $37^{\circ} \mathrm{C}$. Perfusion pressure was continuously monitored with a pressure transducer (Gould Electronics BV, Bilthoven, The Netherlands) placed in series with the perfusion inflow line. The perfusion flow rate was manually adjusted to maintain a constant perfusion pressure of $10 \mathrm{~mm} \mathrm{Hg}$. During reperfusion, $\mathrm{pH}$ and sodium, potassium, magnesium, and calcium ions were monitored and adjusted to maintain physiologic values.

Functional measurements. Arterial and venous blood samples were collected for blood gas analysis (ABL3; Radiometer, Copenhagen, Denmark) and hematocrit evaluation (Cellokrit; AB Lar Lyunberg, Stockholm). Blood electrolytes and $\mathrm{pH}$ adjustments were made as needed during the study period to maintain physiologic arterial blood $\mathrm{pH}$ (7.3-7.4). Arterial samples were taken from the left atrium outflow cannula and venous samples were taken from blood exiting directly from the oxygenator. The arteriovenous oxygen concentration difference $\left(\mathrm{CaO}_{2}-\mathrm{CvO}_{2}\right.$ in milliliters of oxygen per $100 \mathrm{~mL}$ blood) was calculated as follows:

$\mathrm{CaO}_{2}-\mathrm{CvO}_{2}=\left[(1.34 \times \mathrm{Hb}) \times\left(\mathrm{SaO}_{2}\right)\right]-\left[(1.34 \times \mathrm{Hb}) \times\left(\mathrm{SvO}_{2}\right)\right]$

where $S$ is the arterial $\left(\mathrm{SaO}_{2}\right)$ or venous $\left(\mathrm{SvO}_{2}\right)$ oxygen saturation and $\mathrm{Hb}$ is hemoglobin concentration (in grams per deciliter).

The PVR (in millimeters of mercury per milliliter per minute) was calculated from measurements of the blood flow with a flow probe (Statham SP2202; Statham, Inc, Biomedical Division, Oxnard, Calif) and the pulmonary artery pressure (PAP in millimeters of mercury; Kipp and Zonen, Solingen, Germany) and calculated as follows:

$$
\text { PVR }=\frac{\text { PAP }}{\text { Blood flow }}
$$

Complement activity. A quantitative assay was used to detect complement activity of the human blood, (Kallestad Quantiplate; Sanofi Diagnostics Pasteur SA, Paris, France). In brief, human serum was placed in wells and diffused through an agarose gel medium containing standardized sheep erythrocytes sensitized with hemolysin. Total complement activity $\left(\mathrm{CH}_{100}\right)$ was subsequently estimated by comparing the extent of the lysis of the sheep erythrocytes caused by the human serum to that caused by a standard reference serum. By definition, 1 unit of complement $\left(\mathrm{CH}_{100}\right)$ at $\mathrm{pH}$ $7.4,37^{\circ} \mathrm{C}$, in veronal buffer for 60 minutes will lyse $2 \times 10^{8}$ sheep erythrocytes sensitized with $2 \mathrm{U}$ hemolysin. Pathologic $\mathrm{CH}_{100}$ values are $<70 \mathrm{CH}_{100} \mathrm{U} / \mathrm{mL}$.

Immunoglobulins, hemolysis, coagulations, and membrane attack complex in human blood. Levels of total circulating human immunoglobulin $\mathrm{G}$ ( $\operatorname{IgG}$ ), $\operatorname{IgA}$, and $\operatorname{IgM}$ (in grams per liter) were evaluated with class-specific antibodies (Roche Diagnostics, Basel, Switzerland) and measured by end-point turbidity at $340 \mathrm{~nm}$. Lysis of red blood cells was determined by measuring the absorbance of a diluted plasma at $547 \mathrm{~nm}$ with reference to a standard curve of hemoglobin and expressed as milligrams of hemoglobin per $100 \mathrm{~mL}$. Prothrombin time and activated partial thromboplastin time were determined with a fibrin timer 10 semiautomatic device (Behring Austria Diagnostica GmbH, Wien, Austria) by in vitro activation $\left(37^{\circ} \mathrm{C}\right)$ of plasma with human placental thromboplastin (Thromborel S; Behring) and micronized silica (automated activated partial thromboplastin time; Organon Teknika BV, Turnhout, Belgium), respectively. Chronometric determination of fibrinogen level (in grams per liter) was made according to the Clauss method ${ }^{14}$ with an ST 888 semiautomatic device (Diagnostica-Stago, Ansieres, France) by in vitro activation $\left(37^{\circ} \mathrm{C}\right)$ of plasma with bovine thrombin (Fibromat; BioMérieux, Lyon, France). The effects of heparin on the values of the activated partial thromboplastin time were evaluated by the anti-factor Xa activity, which was kept below 0.5 $\mathrm{U} / \mathrm{mL}$.

The quantification of SC5b,6,7,8,9 (membrane attack complex) in human serum was performed with the QUIDEL SC5b,6,7,8,9 enzyme-linked immunosorbent assay (Quidel, San Diego, Calif). Membrane attack complex is usually not expressed in human serum.

Measurement of natural anti- $\alpha$-Gal antibodies. Isotypespecific determination of anti- $\alpha-G a l$ antibodies was performed by enzyme-linked immunosorbent assay. ${ }^{15}$ In brief, microtiter plates (NUNC Maxisorp; NUNC AB, Roskilde, Denmark) were coated with soluble Bdi-PAA conjugates (SYNTESOME GmbH, Munich, Germany). Coating conditions were $4 \mu \mathrm{g} / \mathrm{mL}$ PAA- $\alpha-G a l$ in $0.1 \mathrm{~mol} / \mathrm{L}$ carbonate buffer, $\mathrm{pH} 9.6$, overnight at $4^{\circ} \mathrm{C}$. The plates were then washed with PBS, pH 7.4, containing $0.02 \%$ polysorbate (Tween) 20. The plasma samples were diluted 1:40 in PBS, $\mathrm{pH} 7.4$, containing $1 \%$ bovine serum albumin and $5 \%$ polysorbate 20 and incubated at $100 \mu \mathrm{L} /$ well for 2 hours at $37^{\circ} \mathrm{C}$ on a shaker. After washing, bound anti- $\alpha-G a l$ antibodies were detected with monoclonal antibodies to human IgG (clone 8a4), IgM (AF6), or IgA (2D7). All monoclonal antibodies were mouse IgG1 isotypes purchased from Oxoid (Basingstoke, Great 
Britain). They were in turn revealed by biotinylated goat antimouse IgG1 (SBA, Birmingham, Ala), streptavidin-alkaline phosphatase conjugate (Amersham International, Amersham, Great Britain), and 4-nitrophenyl-phosphate substrate. The absorbance at $405 \mathrm{~nm}$ was measured with a microplate reader (Dynatech, Alexandria, Va). Baselines of anti- $\alpha$-Gal enzymelinked immunosorbent assay determinations were expressed as a percentage of a standard serum (from a healthy blood group $\mathrm{O}$ donor) included in each plate; their modifications after the in situ, in vitro, and ex vivo perfusions were reported as the percentage change from baseline.

Preparation of endothelial cell extracts. Porcine endothelial cells were explanted from the aorta of Large White pigs and cultured until confluence in Roswell Park Memorial Institute medium containing 20\% fetal calf serum and $1 \mathrm{mmol} / \mathrm{L}$ sodium pyruvate. ${ }^{16}$ Endothelial cell monolayers were washed, scraped from the flasks, and reduced to pellets by centrifugation at $900 \mathrm{~g}$ for 5 minutes. The cells were resuspended and lysed in 1 volume of $50 \mathrm{mmol} / \mathrm{L}$ trishydroxymethyl-amino methane (Tris, $\mathrm{pH}$ 7.2) containing $2 \%$ $t$-octylphenoxypolyoxyethanol (Triton X-100), $5 \mathrm{mmol} / \mathrm{L}$ ethylenediaminetetraacetic acid and Pefablock SC (Pentapliarm, Basel, Switzerland), $1 \mathrm{mmol} / \mathrm{L}$ benzamidine, $15 \mu \mathrm{mol} / \mathrm{L}$ pepstatin, and $10 \mu \mathrm{mol} / \mathrm{L}$ leupeptin for 30 minutes on ice. After centrifugation at $10,000 \mathrm{~g}$ for 30 minutes, the supernatant was collected and stored at $-70^{\circ} \mathrm{C}$ until used.

Sodium dodecyl sulfate-polyacrylamide gel and Western blot analysis. Samples of endothelial cell extracts were electrophoresed on a $7.5 \%$ gel under reducing conditions. Proteins resolved in this way were transferred to $0.45-\mu \mathrm{m}$ polyvynillidene difluoride membranes, ${ }^{16}$ After saturation with 3\% low-fat dry milk in Tris-buffered saline solution (TBS) overnight at $25^{\circ} \mathrm{C}$, the membranes were washed 3 times with $0.3 \%$ polysorbate 20 in TBS and stored in this buffer until used. Human serum samples were diluted 1:20 in TBS and incubated overnight at $25^{\circ} \mathrm{C}$. After washing with $0.3 \%$ polysorbate 20 in TBS, antibody binding was detected by incubating blots with alkaline phosphatase-conjugated affinity-purified $\mu$-chain-specific goat antihuman $\operatorname{IgM}$ or $\gamma$ chain-specific goat antihuman IgG (The Jackson Laboratories, Bar Harbor, Me) diluted 1:1000 in $0.5 \%$ bovine serum albumin in TBS for 2 hours at $25^{\circ} \mathrm{C}$. The expression of $\alpha$-Gal residues was analyzed in parallel with either biotinylated isolectin B4 from Griffonia simplicifolia (GSI-B4) ${ }^{16}$ or a monoclonal antibody specific for Gal- $\alpha-(1,3) \mathrm{Gal}$ diluted 1:4 in TBS and stained with alkaline phosphatase-conjugated affinity purified goat antimouse immunoglobulins $(\mathrm{H}+\mathrm{L}$; Jackson). The immunoblots were revealed with the nitroblue tetrazolium procedure (Biorad, Hercules, Calif).

Histologic examination. The in situ and ex vivo perfused pig organs were assessed macroscopically. At least 4 samples of representative areas were taken, and fragments were fixed in $10 \%$ formaldehyde and routinely processed into paraffin wax. Sections were cut at $5 \mu \mathrm{m}$ and stained with hematoxylin and eosin. Sections from paraffin blocks were also used for immunohistochemical studies performed with the LSAB Kit (Dako SA, Trappes, France). Rabbit antibodies were as fol-
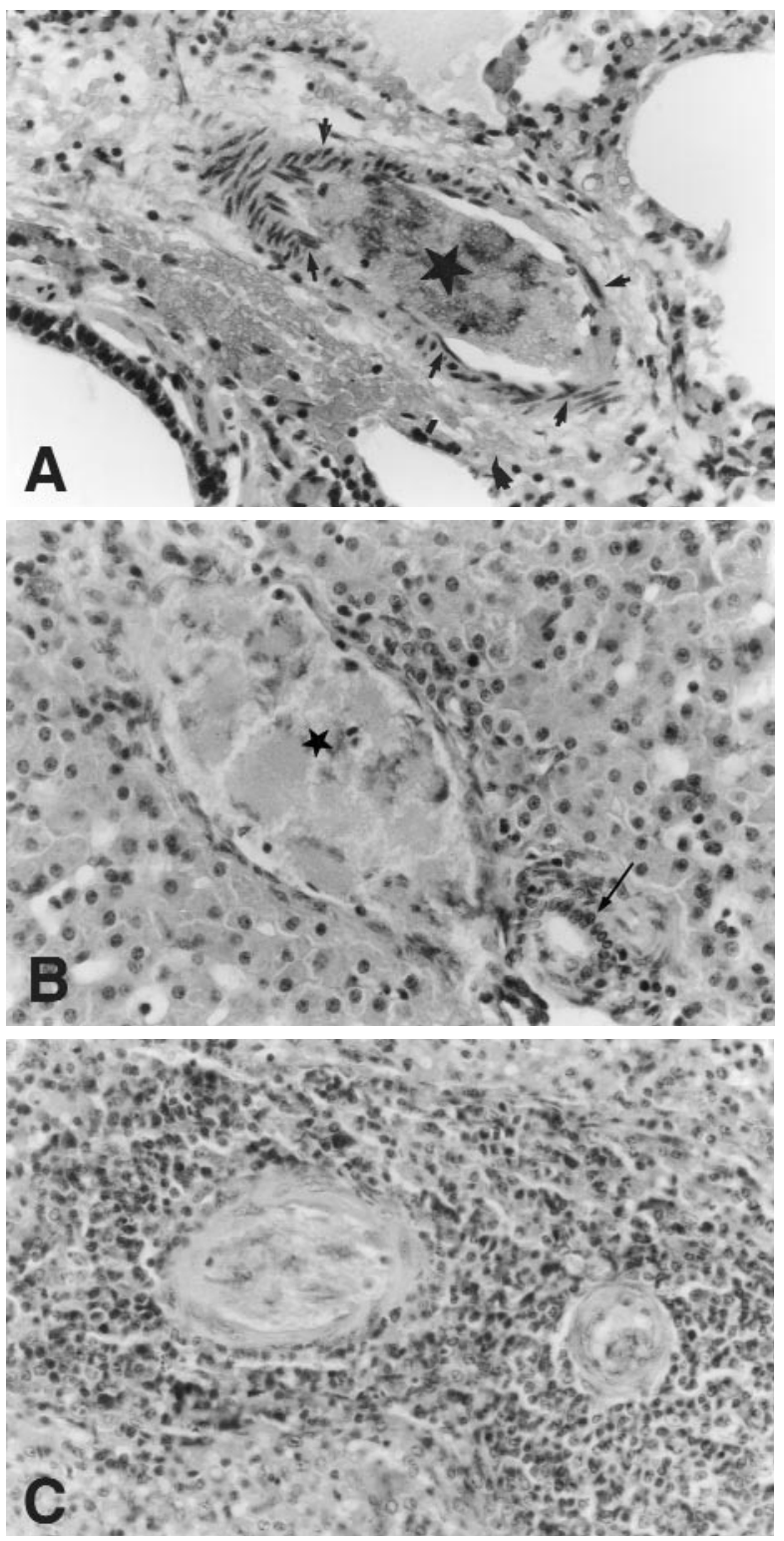

Fig 2. Histologic signs of hyperacute rejections after in situ perfusion of pig donor organs with human blood. A, Recent fibrin and platelets thrombus (star) occluding the lumen of an alveolocapillary vessel; arrows indicate platelets on the capillary endothelium. B, Portal vein containing a recent thrombus made up by fibrin and platelets (star). The adjacent biliary duct (arrow) and liver parenchyma are normal. C, Two sections of a small artery in the white pulp of the spleen. The lumen is occluded with fibrin and platelets, forming a thrombus. (Original magnification $\times 350$.)

lows: antihuman IgM and IgG diluted 1:1000 and anti-C3 diluted 1:30 (Biogenex-Menarini, Chevilly-Larue, Paris, France).

Fresh tissue was snap-frozen in liquid nitrogen and stored 
Table I. Percentage decline from baseline values of anti- $\alpha$-Gal xenoreactive antibodies in human blood during the in situ, in vitro, and ex vivo experiments

\begin{tabular}{lccccc}
\hline & Timing & Right lung & Liver & Spleen & $\alpha$-Gal column \\
\hline IgM anti- $\alpha$-Gal & Baseline & $68 \pm 26(100 \%)$ & $41 \pm 13(100 \%)$ & $53 \pm 24(100 \%)$ & $45 \pm 14(100 \%)$ \\
& After & $88 \pm 6$ & $72 \pm 12$ & $79 \pm 9$ & $93 \pm 5$ \\
& 10 min & $88 \pm 5$ & $77 \pm 8$ & $83 \pm 6$ & $97 \pm 1$ \\
& 60 min & $87 \pm 6$ & $77 \pm 25$ & $75 \pm 15$ & $94 \pm 4$ \\
IgG anti- $\alpha-G a l$ & 180 min & $85 \pm 10$ & $80 \pm 28$ & - & - \\
& Baseline & $68 \pm 37(100 \%)$ & $42 \pm 16(100 \%)$ & $106 \pm 8(100 \%)$ & $21 \pm 11(100 \%)$ \\
& After & $93 \pm 5$ & $84 \pm 18$ & $91 \pm 10$ & $88 \pm 13$ \\
IgA anti- $\alpha-$ Gal & 10 min & $96 \pm 2$ & $88 \pm 13$ & $96 \pm 3$ & $91 \pm 11$ \\
& 60 min & $97 \pm 2$ & $88 \pm 10$ & $96 \pm 3$ & - \\
& 180 min & $96 \pm 3$ & $66 \pm 38(100 \%)$ & $115 \pm 52(100 \%)$ & $48 \pm 23(100 \%)$ \\
& Baseline & $69 \pm 17(100 \%)$ & $45 \pm 25$ & $83 \pm 13$ & $75 \pm 19$ \\
& After & $77 \pm 18$ & $67 \pm 24$ & $85 \pm 13$ & $89 \pm 7$ \\
& 10 min & $87 \pm 10$ & $68 \pm 25$ & - & $78 \pm 10$
\end{tabular}

Results (mean \pm standard deviation) are expressed as (1) baseline values of anti- $\alpha$-Gal xenoreactive antibodies (compared to a standard serum) and (2) percentage decline from baseline after in situ (pig donor organs) or in vitro ( $\alpha$-Gal column) absorption and after 10, 60 and 180 min of ex vivo lung perfusion. After in vivo or in vitro absorption, the anti- $\alpha-$ Gal IgG and IgM were significantly better absorbed than anti- $\alpha$-Gal $\operatorname{IgA}(P=.005)$ and the percentage of absorbed anti- $\alpha$-Gal antibodies was significantly higher $(P=.02)$ after the in vitro than the lung but not spleen or liver in situ preperfusion. The liver absorbed in time a significantly lower percentage of anti- $\alpha$-Gal than the right lung $(P=.04)$ and the $\alpha$-Gal column $(P=.001$, IgM), the right lung $(P=.01, \operatorname{IgG})$, and right lung $(P<.0001)$, spleen $(P=.002)$, and the $\alpha-$ Gal column $(P=.003, \operatorname{Ig} \mathrm{A})$.

at $-70^{\circ} \mathrm{C}$. Immunostaining was carried out on cryostat sections by direct fluorescence. Fluorescein isothiocyanate-conjugated rabbit antibodies (Dako) were used diluted 1:10; antihuman IgM, C1q, C3, and antifibrinogen or anti-IgG were diluted 1:20.

Statistical analysis. All quantitative serum or plasma data were normalized for hemodilution by correcting them for changes in hematocrit value. Xenograft failure was defined as such when the ex vivo lung perfusion was associated with no gas exchange, severe pulmonary hypertension, and gross evidence of pulmonary hemorrhage and edema. Experiments were stopped at the occurrence of xenograft failure or at consumption of the blood volumes (for functioning xenografts). Data are expressed as mean \pm standard deviation of the number of observations and analyzed by 1-way analysis of variance with the Fisher protected least significance difference. Data were analyzed with a software package (STATVIEW 4.02; Abacus Concepts, Inc, Berkeley, Calif).

\section{Results}

In situ and in vitro absorption. All isolated pig donor organs perfused in situ with human blood were hyperacutely rejected; they were congestive and hemorrhagic and displayed fibrin and platelet thrombi obstructing the alveolar capillaries, the portal sinuses, or the splenic microvessels (Fig 2). Only pig livers showed infiltration by inflammatory cells. The immunohistologic analysis of these organs showed diffuse vascular staining of C1q, C3, fibrinogen, and IgM.

After the in situ and in vitro perfusions, between $45 \%$ and $93 \%$ of anti- $\alpha-$ Gal human antibodies were removed from the human blood; a second marginal decline in the anti- $\alpha$-Gal xenoantibodies titers was observed 10 minutes after the ex vivo reperfusion but remained stable thereafter (Table I). To compare the specificity of antibody depletion, the reactivity of human serum samples was analyzed on porcine endothelial cell extracts before and after pig organ or column adsorption. Before antibody depletion at least 10 bands corresponding to proteins with apparent molecular weights of 250, 180, 160, 135,110 to $120,95,80,65$ to 70,45 to 50 , and 25 to 35 $\mathrm{kDa}$ were revealed by human IgM and IgG (Fig 3, $A$ and $B$, lanes 1 and 3 ). The pattern of reactivity depended on the serum used, but the most intensively reactive bands generally migrated between 135 and $250 \mathrm{kDa}$. These bands were also $\alpha$-galactosylated, as assessed by GSIB4 lectin binding (data not shown) and anti- $\alpha$-Gal monoclonal antibody binding (Fig 3, $A$ and $B$, lane 5). After immunoadsorption on the $\alpha$-Gal column, binding of both IgG and IgM to the $135-\mathrm{kD}$ a protein was removed, whereas binding to other proteins remain unchanged (Fig 3, $A$ and $B$, lane 2). In contrast, after perfusion of porcine lung antibody reactivities against the $135-\mathrm{kDa}$ protein but also against other proteins with lower molecular weights of 30 to 34 and $26 \mathrm{kDa}$ were lost, and antibody binding against proteins of 70 to 90 and of 45 to $55 \mathrm{kDa}$ was decreased (Fig 3, $A$ and $B$, lane 4). Similar but weaker results were also observed after pig liver perfusion (data not shown). 


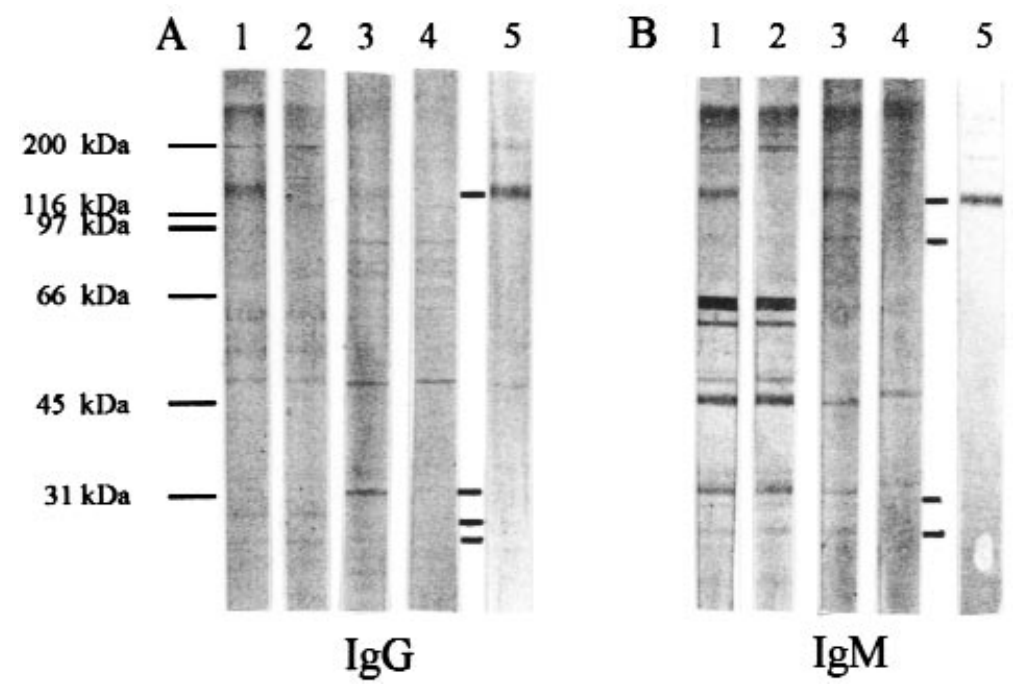

Fig 3. Representative western blot analysis of 3 independent experiments, analysis of the reactivity of human serum before and after natural antibody immunoadsorption. Porcine aortic endothelial cell membrane extracts were separated by sodium dodecyl sulfate-polyacrylamide gel electrophoresis, blotted onto polyvynillidene difluoride and then stained as follows: lane 1, human serum, before depletion; lane 2, human serum, after in vitro depletion on the $\alpha$-Gal column; lane 3, human serum, before depletion; lane 4 , human serum, after in situ perfusion of the right lung; lane 5, monoclonal anti- $\alpha$-Gal antibody. Molecular weight standards are shown on the left. Between lanes 4 and 5 is illustrated the position of the bands that disappear after absorption in lanes 2 and 4 . Antibody binding was revealed with antihuman $\operatorname{IgG}(\mathbf{A}), \operatorname{IgM}(\mathbf{B})$, or antimouse $\operatorname{Ig}$ (lane 5) alkaline phosphatase-conjugated secondary reagents.

Table II. Functioning survival time of the ex vivo perfused pig lungs

\begin{tabular}{lcccc}
\hline & \multicolumn{2}{c}{ Xenograft survival (min) } & & \multicolumn{2}{c}{$\begin{array}{c}\text { Functioning xenografts } \\
\text { at the end of experiments }\end{array}$} \\
\cline { 2 - 4 } Type of absorption & Median & Range & Number & 100 \\
\hline Right lung & 300 & $240-360$ & $6 / 6$ & 33 \\
Liver & 150 & $90-180$ & $2 / 6$ & 0 \\
Spleen & 60 & $30-120$ & $0 / 6$ & 0 \\
Q-Gal column & 105 & $30-120$ & $0 / 6$ &
\end{tabular}

Xenograft failure was defined as such when the ex vivo lung perfusion was associated with no gas exchange, severe pulmonary hypertension, and gross evidence of pulmonary hemorrhage and edema.

Ex vivo lung perfusion. All group I xenografts were functionally working after a median of 300 minutes (range 240-360 minutes) of ex vivo reperfusion, and their functional survival time was significantly $(P<$ .0001 ) better than that of the other xenografts (Table II). Xenograft failure occurred in 4 lungs belonging to group II and in all group III and IV lungs $(P<.0001)$. The PVR and $\mathrm{CaO}_{2}-\mathrm{CvO}_{2}$ of group I xenografts were significantly better than those observed in the other xenografts (Fig 4).

Group I left lung xenografts were always normal in histologic and immunohistologic appearance at the end of the perfusions, showing only isolated areas of alve- olar edema. In contrast, all xenografts belonging to the other groups showed severe alveolar edema but no thrombotic events within the lung capillary beds (Fig 5); on immunohistologic examination, their alveolar capillaries stained weakly with C3 (Fig 6).

Effects of the in situ, in vitro, and ex vivo experiments on the human blood. The hematocrit levels remained stable through the study periods in the preperfused lung and $\alpha$-Gal column human blood but increased significantly in the samples of the preperfused spleen (Fig 7). Except for the white blood cells (Fig 8), the human blood reperfusing group I lung xenografts showed a significant lower decline of coagulation fac- 

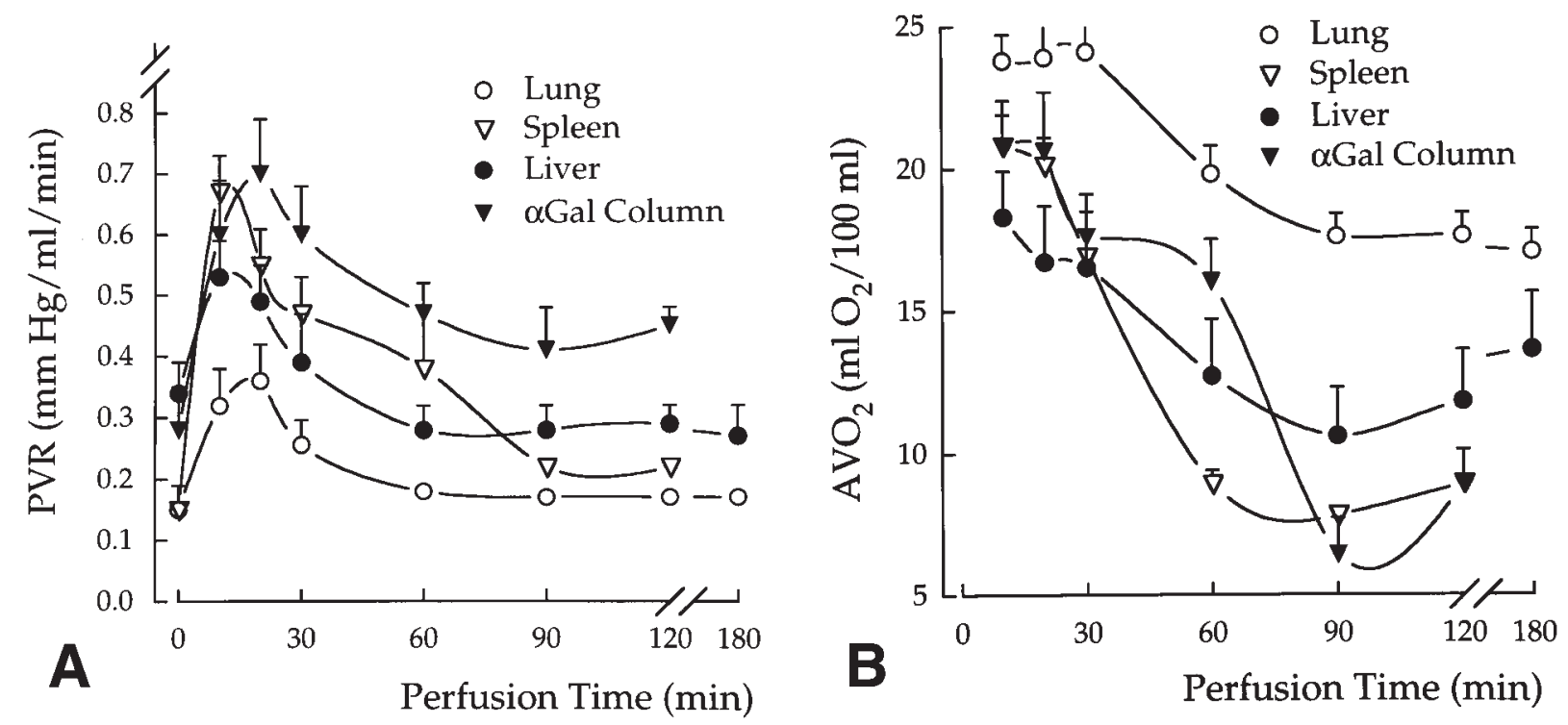

Fig 4. A, PVR at baseline (time 0) and at specific intervals after perfusion of pig left lung with the in situ (pig organ) or in vitro ( $\alpha$-Gal column) preperfused human blood. The PVR of the left lung was significantly lower when the human blood was preperfused through the right lung than when it was preperfused through the liver $(P=.0002)$, spleen $(P=.001)$, or $\alpha-$ Gal column $(P<.0001)$. The normal PVR values observed in pig lungs perfused with autogenic blood are $<0.25 \mathrm{~mm} \mathrm{Hg} / \mathrm{mL} / \mathrm{min}$ according to Macchiarini, Mazmanian, and Oriol. ${ }^{3} \mathbf{B}$, Oxygen extraction, reflected by $\mathrm{CaO}_{2}-\mathrm{CvO}_{2}(\mathrm{AVO} 2)$ of pig lung at specific intervals after perfusion of pig left lung with the in situ (pig organ) or in vitro ( $\alpha$-Gal column) previously perfused human blood. Hemoglobin concentrations to calculate $\mathrm{CaO}_{2}-$ $\mathrm{CvO}_{2}$ were normalized for the observed hematocrit. $\mathrm{CaO}_{2}-\mathrm{CvO}_{2}$ of pig left lung perfused with human blood preperfused through the right lung was significantly better than with the other preperfusion strategies (liver, $P<.0001$; spleen, $P=.008$; $\alpha$-Gal column, $P=.0007)$. The normal $\mathrm{CaO}_{2}-\mathrm{CvO}_{2}$ values observed in pig lung perfused with autogenic blood are between 20 and $25 \mathrm{~mL}$ oxygen $/ 100 \mathrm{~mL}$. Data are expressed as mean \pm standard deviation (error bars).

tors (Table III), total circulating immunoglobulins (Table IV), and activation of $\mathrm{CH}_{100}$ (Fig 9), membrane attack complex (Fig 10), and hemolysis (Fig 11) than did groups II, III, and IV during the study period.

\section{Discussion}

Preformed natural antibodies of both IgM and IgG isotypes in human beings and Old World monkeys represent a major hurdle to discordant xenotransplantation by initiating hyperacute rejection within minutes to hours. ${ }^{6}$ Recent investigations have defined the main antigenic target of human xenoantibodies as being the terminal galactose residue in $\alpha 1-3$ linkage Gal $\alpha(1-$ 3) $\mathrm{Gal},{ }^{17,18}$ which is densely distributed along the vascular endothelium of all porcine organs, including the heart, lung, liver, kidney, and pancreas. ${ }^{19}$ One percent of the human B cells are capable of producing anti- $\alpha$ Gal antibodies, ${ }^{14}$ and approximately $80 \%$ of the preformed human antipig xenoantibodies are specific for this epitope. ${ }^{20}$ Unsurprisingly, and in analogy with ABO-incompatible ${ }^{21}$ and HLA-incompatible and hyperimmunized allotransplants, ${ }^{22}$ removal of anti- $\alpha-$
Gal natural antibodies from the primate circulation by plasma exchange, ${ }^{21}$ pig donor organ absorption, ${ }^{7,23-26}$ or column immunoabsorption ${ }^{15,27}$ has been investigated. Despite some limitations of each of these approaches, ${ }^{5}$ increasing experimental and clinical evidence suggests that these antibody-depleting procedures can prolong pig to primate organ xenograft survival from minutes to several days.

Selective column immunoabsorption offers a more clinically attractive option than pig donor organ perfusion to remove xenoantibodies from the circulation of xenograft recipients because of its hemodynamic stability $^{27}$ and limited effects on the coagulation system and plasma protein levels. ${ }^{15}$ In addition, the possibility of repeated use in the peritransplantation period makes it more practical. However, the 2 antibody-depleting strategies prolong pig kidney $^{27}$ xenograft survival equally. In this study the amount of anti- $\alpha$-Gal removed by column immunoabsorption was significantly higher than that removed by pig lung perfusion $(90 \% \pm 3 \%$ vs $78 \% \pm 4 \%$, respectively). Although the reduction of anti- $\alpha-G a l$ was incomplete, both techniques were able 


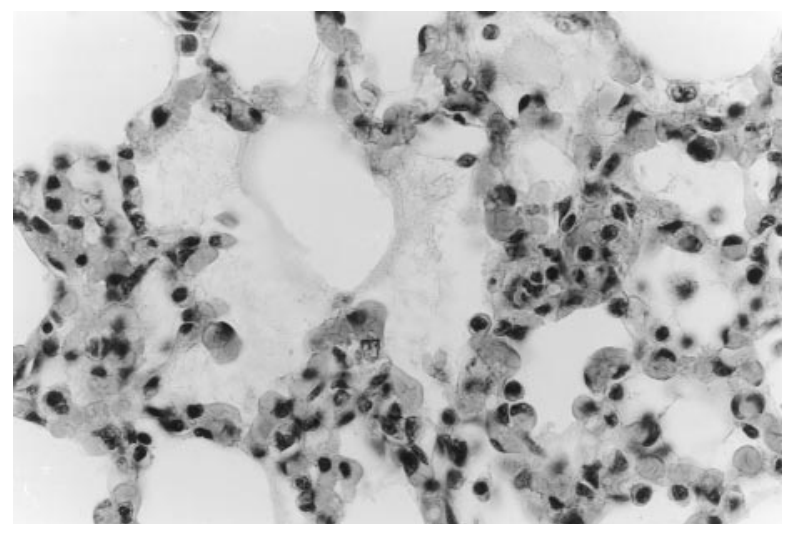

Fig 5. Histologic appearance of pig left lung perfused with the human blood preperfused in situ through pig spleen. The alveolar capillaries are dilated and packed with red blood cells but without intravascular thrombi. The edema is characterized by a proteinaceous fluid within the alveolar lumens. (Original magnification $\times 530$.)
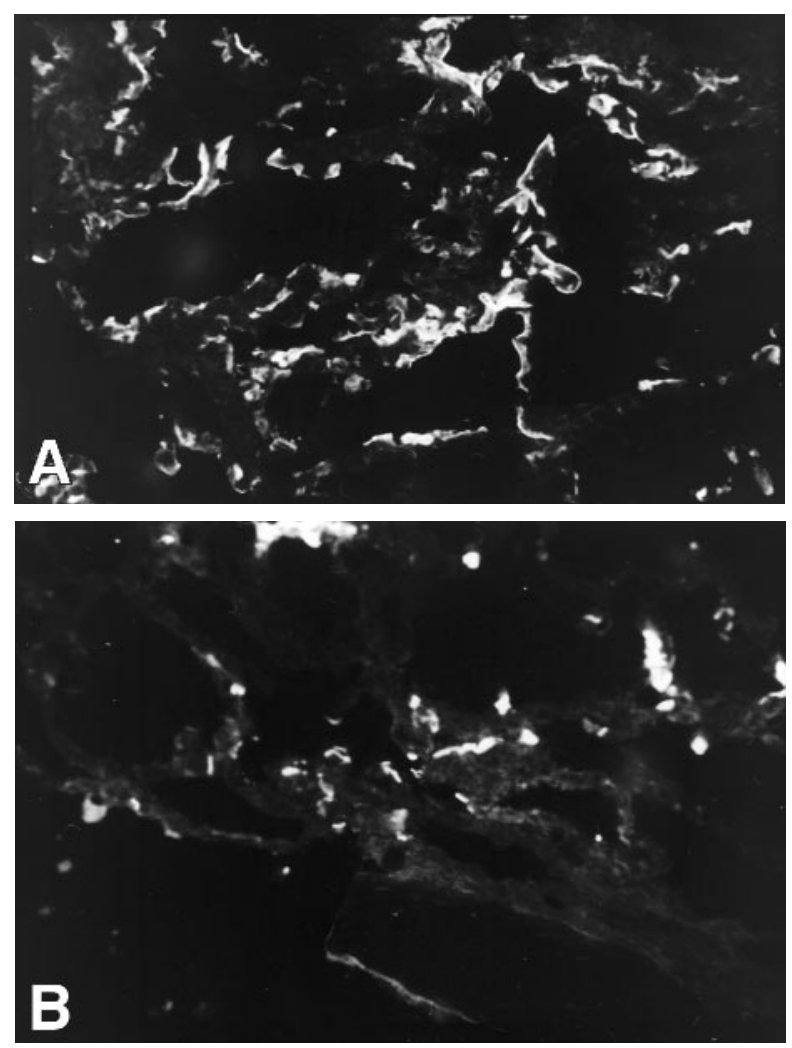

Fig 6. Immunofluorescence with antihuman $\mathrm{C} 3$. The strong deposition usually observed after perfusion of pig lung with untreated human blood (A, hyperacute rejection) is compared with the weak deposition (B) observed along the alveolar capillaries of an ex vivo pig lung perfused with human blood absorbed through pig liver. (Original magnification $\times 200$.)

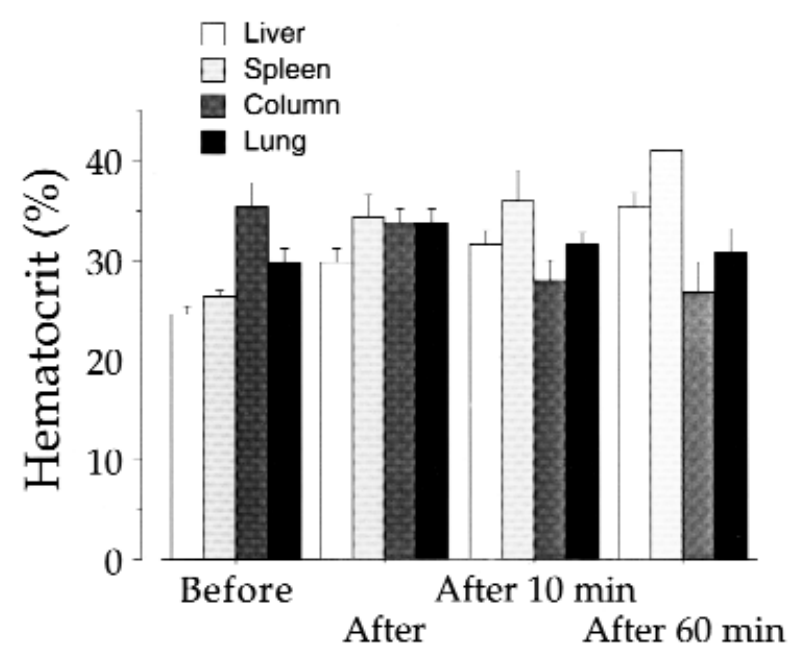

Fig 7. Hematocrit before and after the in situ or in vitro absorptions and after 10 and 60 minutes of the ex vivo left lung perfusion with human blood. Data are expressed as mean \pm standard deviation (error bars). The human blood absorbed through spleen displayed a significantly higher hematocrit increase during the study periods than that absorbed with liver $(P=.01)$ or $\alpha$-Gal column $(P=.03)$.

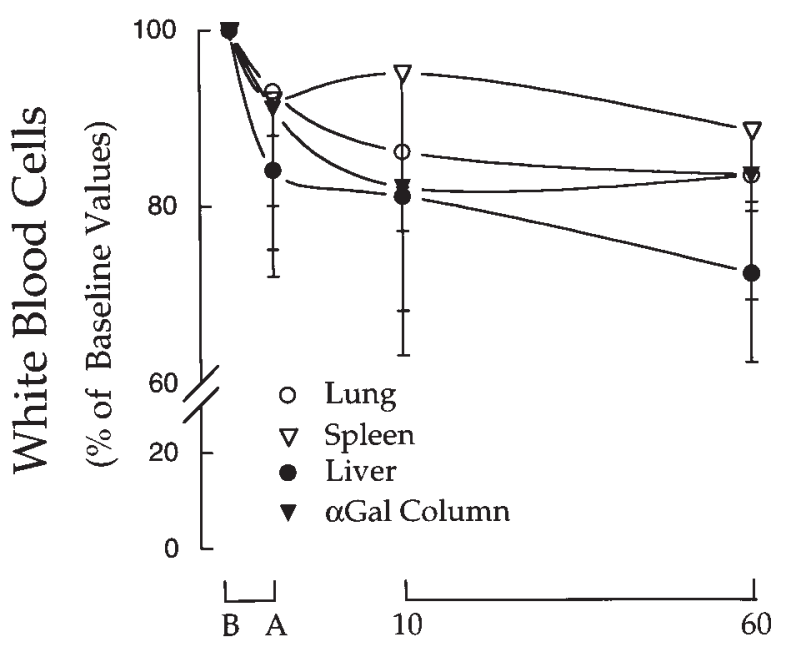

Fig 8. Human white blood cells before (B) and after (A) the in situ or in vitro absorptions and after 10 and $60 \mathrm{~min}$ utes of the ex vivo left lung perfusion. The decline in white blood cells in the human blood absorbed through pig liver was significantly lower than that observed in blood absorbed through right lung $(P=.04)$, spleen $(P=.0005)$, and $\alpha$-Gal column $(P=.02)$. Data are expressed as mean \pm standard deviation (error bars) of the experiments and normalized for the observed hematocrit. Baseline white blood cells were $8983 \pm 844$ cells $/ \mathrm{mm}^{3}, 5600 \pm 400$ cells/ $\mathrm{mm}^{3}, 6500 \pm 900$ cells $/ \mathrm{mm}^{3}$, and $7083 \pm 384$ cells $/ \mathrm{mm}^{3}$ for the liver, spleen, $\alpha-G a l$ column, and right lung groups, respectively. 
Table III. Modifications of human coagulation factors during the in situ, in vitro, and ex vivo experiments

\begin{tabular}{|c|c|c|c|c|c|}
\hline & Timing & Right lung & Liver & Spleen & $\alpha$-Gal column \\
\hline \multirow[t]{4}{*}{ Platelets $\left(\times 1000 / \mathrm{mm}^{3}\right)$} & Before & $465 \pm 41$ & $600 \pm 43$ & $494 \pm 5$ & $298 \pm 56$ \\
\hline & After & $311 \pm 40$ & $339 \pm 46$ & $312 \pm 12$ & $232 \pm 69$ \\
\hline & $10 \mathrm{~min}$ & $314 \pm 42$ & $263 \pm 19$ & $265 \pm 86$ & $110 \pm 82$ \\
\hline & $60 \mathrm{~min}$ & $300 \pm 52$ & $230 \pm 12$ & $224 \pm 17$ & $102 \pm 72$ \\
\hline \multirow[t]{4}{*}{ APTT (sec) } & Before & $37 \pm 3$ & $40 \pm 5$ & $47 \pm 12$ & $38 \pm 4$ \\
\hline & After & $42 \pm 5$ & $52 \pm 10$ & $75 \pm 25$ & $62 \pm 30$ \\
\hline & $10 \mathrm{~min}$ & $47 \pm 5$ & $61 \pm 18$ & $107 \pm 17$ & $74 \pm 36$ \\
\hline & $60 \mathrm{~min}$ & $54 \pm 6$ & $65 \pm 23$ & $120 \pm 12$ & $98 \pm 13$ \\
\hline \multirow[t]{4}{*}{ PTT (sec) } & Before & $38 \pm 3$ & $43 \pm 2$ & $41 \pm 4$ & $67 \pm 7$ \\
\hline & After & $43 \pm 2$ & $55 \pm 7$ & $52 \pm 8$ & $53 \pm 13$ \\
\hline & $10 \mathrm{~min}$ & $50 \pm 2$ & $62 \pm 5$ & $63 \pm 20$ & $54 \pm 11$ \\
\hline & $60 \mathrm{~min}$ & $54 \pm 3$ & $67 \pm 6$ & $75 \pm 33$ & $79 \pm 9$ \\
\hline \multirow[t]{4}{*}{ Fibrinogen $(\mathrm{g} / \mathrm{L})$} & Before & $2.8 \pm 0.1$ & $2.3 \pm 0.1$ & $2.5 \pm 0.2$ & $2.5 \pm 0.4$ \\
\hline & After & $2.1 \pm 0.1$ & $1.3 \pm 0.1$ & $1.6 \pm 0.3$ & $1.2 \pm 0.4$ \\
\hline & $10 \mathrm{~min}$ & $1.5 \pm 0.1$ & $0.9 \pm 0.1$ & $0.8 \pm 0.3$ & $0.9 \pm 0.3$ \\
\hline & $60 \mathrm{~min}$ & $1.4 \pm 0.1$ & $0.8 \pm 0.1$ & $0.8 \pm 0.3$ & $0.8 \pm 0.3$ \\
\hline
\end{tabular}

Data are expressed as mean \pm standard deviation. APTT, activated partial thromboplastin time; $P T$, prothrombin time. Comparison between values before and after in situ (pig donor organs) or in vitro ( $\alpha$-Gal column) absorption and after 10 and 60 minutes of ex vivo perfusion experiments.

Table IV. Modification of total human immunoglobulins during the in situ, in vitro and ex vivo experiments

\begin{tabular}{lccccc}
\hline & Timing & Right lung & Liver & Spleen & $\alpha$-Gal column \\
\hline $\operatorname{IgG}(\mathrm{g} / \mathrm{L})$ & Before & $23 \pm 1$ & $29 \pm 3$ & $36 \pm 10$ & $17 \pm 5$ \\
& After & $18 \pm 1$ & $16 \pm 3$ & $10 \pm 2$ & $15 \pm 3$ \\
& 10 min & $18 \pm 1$ & $12 \pm 2$ & $8 \pm 3$ & $12 \pm 3$ \\
$\operatorname{IgM}(\mathrm{g} / \mathrm{L})$ & 60 min & $17 \pm 2$ & $11 \pm 1$ & $7 \pm 2$ & $10 \pm 3$ \\
& Before & $2 \pm 0.1$ & $3.7 \pm 1$ & $6.4 \pm 1$ & $1.7 \pm 0.4$ \\
& After & $1.6 \pm 0.1$ & $2 \pm 0.3$ & $1.5 \pm 0.5$ & $1.4 \pm 0.3$ \\
$\operatorname{IgA}(\mathrm{g} / \mathrm{L})$ & 10 min & $1.6 \pm 0.1$ & $1.6 \pm 0.3$ & $1 \pm 0.7$ & $1.2 \pm 0.3$ \\
& 60 min & $1.6 \pm 0.1$ & $1.3 \pm 0.2$ & $1 \pm 0.5$ & $1.1 \pm 0.3$ \\
& Before & $6.8 \pm 1$ & $6.1 \pm 1$ & $6.4 \pm 2$ & $5.9 \pm 1$ \\
& After & $5 \pm 0.5$ & $3.4 \pm 1$ & $1 \pm 1$ & $4 \pm 1$ \\
& 10 min & $4.6 \pm 1$ & $3 \pm 0.6$ & $1 \pm 1$ & $3 \pm 1$ \\
\hline
\end{tabular}

Data are expressed as mean \pm standard deviation. Comparison between values of immunoglobulin before and after in situ (pig donor organs) or in vitro ( $\alpha$-Gal column) absorption and after 10 and 60 minutes of ex vivo perfusion experiments.

to prevent the formation of platelet and fibrin thrombi occluding the alveolar-capillary vessels of the ex vivo perfused pig lungs, the classic sign of hyperacute lung rejection in pig to human xenotransplants. ${ }^{2,3}$ This confirms in vitro and in vivo studies ${ }^{28}$ proving that complete xenoantibody absorption is unnecessary to prevent hyperacute rejection. It may be that the fraction of anti$\alpha$-Gal xenoantibodies that were not absorbed by either strategy are of low affinity and do not appear to play a pivotal role in the genesis of lung hyperacute rejection.

However, because only the in situ pig donor lung perfusion completely prevented xenograft failure of a subsequently ex vivo working pig lung, it is not hazardous to postulate that the $\alpha$-Gal barrier is not the only factor responsible for the hyperacute lung rejection in the pig to human combination. Other non- $\alpha$-Gal xenoantibodies, absorbed by the pig donor lung but not by the $\alpha$-Gal column, may react against non- $\alpha-$ Gal epitope xenoantigens expressed on pig lung and induce xenograft dysfunction on ex vivo reperfusion. This assumption is endorsed by the Western blot analysis, in which antibodies to the highly $\alpha$-galactosylated major protein with molecular weight of $135 \mathrm{kDa}$ were removed by both $\alpha$-Gal column and pig organ perfusion, and this is in line with previous studies. ${ }^{29}$ However, antibodies against other proteins with lower molecular weight were depleted by pig donor lung and, to a lesser extent, by liver perfusion but were not removed by the $\alpha-\mathrm{Gal}$ column. This finding is in accordance with previous Western blot analysis performed after pig liver ${ }^{30}$ perfu- 


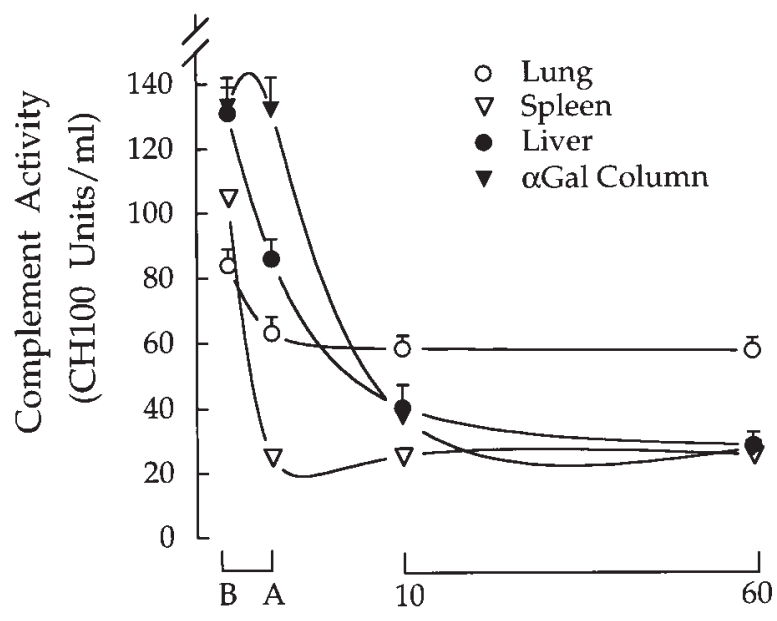

Fig 9. $\mathrm{CH}_{100}$ in human plasma before (B) and after (A) the in situ or in vitro absorptions and after 10 and 60 minutes of the ex vivo left lung perfusion. Data are expressed as mean \pm standard deviation (error bars). The $\mathrm{CH}_{100}$ of the human plasma absorbed through pig right lung declined significantly less than that absorbed through the liver $(P=.02)$, spleen $(P<.0001)$, or $\alpha$-Gal column $(P=.02)$. Reference physiologic value is $<70 \mathrm{CH}_{100} \mathrm{U} / \mathrm{mL}$.

sion and suggests that antibody depletion through pig donor organ perfusion removes antibodies involved in the genesis of hyperacute rejection that are not removed after the $\alpha$-Gal column immunoadsorption.

Lung, liver, and spleen in situ absorbed almost equal percentages of human $\alpha$-Gal xenoantibodies from human blood. However, when absorption rates were normalized for pig organ weight and natural $\alpha-G a l$ xenoantibodies levels before perfusion, the lung absorbed 1.5 and 17 times more xenoantibodies per gram of tissue than did spleen and liver, respectively (data not shown). Comparing the immunoabsorptive capacity of lung tissue observed in this study it appears that the lung is, from a quantitative viewpoint, a more potent $\alpha$-Gal absorbent than liver or spleen. From a qualitative point of view, the plasma and cellular modifications of the human blood reperfusing the ex vivo lungs were of significantly less clinical relevance when pig lung was used to deplete anti- $\alpha-G a l$ antibody from the human blood than with other strategies or other organ perfusion. ${ }^{25,27}$ In effect, pig lung perfusion caused significantly less depletion of coagulation proteins, complement activation, and therefore hemolysis, rendering it a more clinically acceptable intervention, especially in light of recent in vivo evidence ${ }^{27}$ demonstrating that removal of xenoantibody alone, without

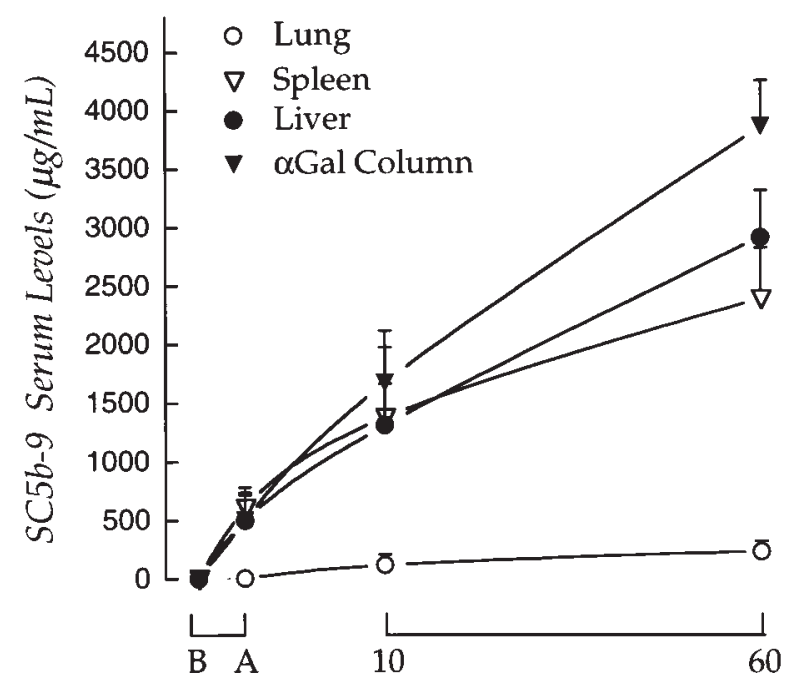

Fig 10. Membrane attack complex (SC5b-9) activation in the human serum before (B) and after (A) the in situ or in vitro absorptions and after 10 and 60 minutes of the ex vivo left lung perfusion. Data are expressed as mean \pm standard deviation (error bars). The difference between the lung and the other absorption methods was significantly different $(P=$ .0001). Reference physiologic value is $0 \mu \mathrm{g} / \mathrm{mL}$.

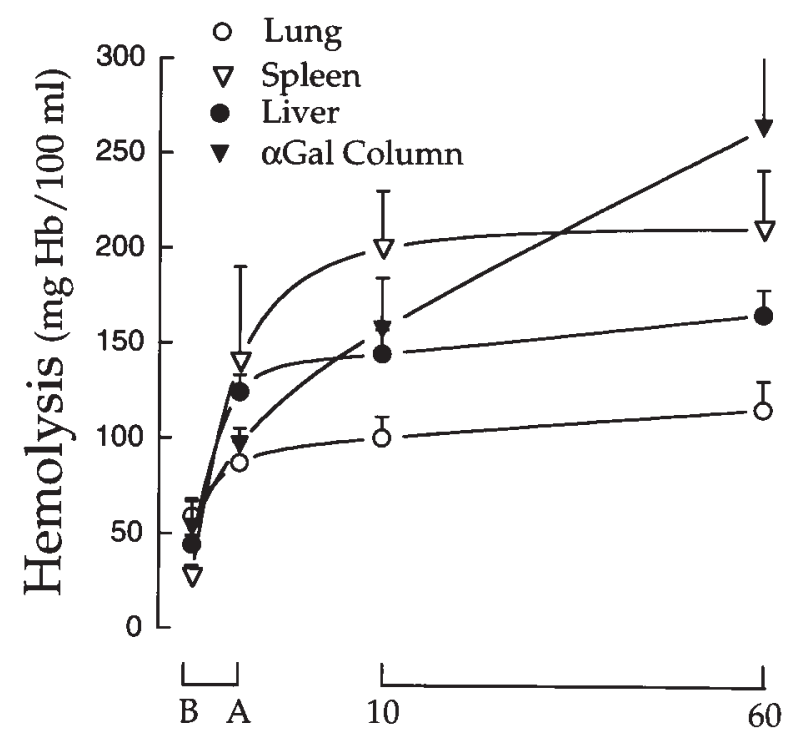

Fig 11. Hemolysis in human plasma before (B) and after (A) the in situ or in vitro absorptions and after 10 and 60 minutes of the ex vivo left lung perfusion. Data are expressed as mean \pm standard deviation (error bars). The hemolysis of the human plasma absorbed through pig right lung was significantly lower than that absorbed through liver $(P=.04)$, spleen $(P=.018)$, or $\alpha$-Gal column $(P=.001)$. Reference physiologic value is $<150 \mathrm{mg} \mathrm{Hb} / 100 \mathrm{~mL}$ ). 
specific complement intervention, prevents hyperacute rejection of a transplanted pig kidney.

The ex vivo lung xenografts perfused with human blood and preperfused through pig right lung were functionally working and histologically intact for longer than 5 hours on reperfusion. In contrast, all but 2 liver preperfused xenografts lost their function well before this time, and their histologic examination always showed pulmonary congestion and severe alveolar edema. Because all harvesting procedures were performed in a similar fashion, the interpretation of this is that only the absorption of human blood through pig donor right lung prevents hyperacute rejection for at least 5 hours. Whether this is due to a higher immunoabsorptive capacity or, more likely, to organ-specific (non- $\alpha-\mathrm{Gal}$ ) xenoantibody depletion by lung tissue remains to be determined. This last explanation is more realistic because in our laboratory with a pig to goat orthotopic lung xenotransplantation model (unpublished results), cross-perfusion of goat blood through right pig donor lung totally prevented the hyperacute rejection of the implanted left pig lung, even after clamping of the contralateral pulmonary artery. This observation is even more important if we take into account that both species do not have anti- $\alpha-G a l$ antibodies in their circulation and that pig lungs orthotopically implanted into goats show a hyperacute rejection similar to that observed in the ex vivo pig to human lung model. ${ }^{3}$

The results of this study provide evidence that specific depletion of anti- $\alpha-G a l$ antibodies alone incompletely protects pig lung from hyperacute rejection. We speculate that the more complete prevention of this rejection afforded by pig lung preperfusion is related to the removal of other non- $\alpha-G a l$ antibodies.

We thank U. Galili for the kind gift of the anti- $\alpha$-Gal monoclonal antibody. We also express our gratitude for the excellent technical assistance of Chantal Verriest, Rémi Burel, Pascal Gusmini, Hegésippe Langouste, Bruno Baudet, Aline Perrin, and Sylvie Planté. The photographic contribution of Denis Petraz is acknowledged. Special thanks are directed to Drs Guiard Jean, Poutiers Philippe, and Bap Charly for their help in supervising the human blood units.

\section{REFERENCES}

1. Platt JL, Vercelotti GM, Dalmasso AP. Transplantation of discordant xenografts: A review of progress. Immunol Today 1990;11:450-6.

2. Pierson RN, Kasper-Konig W, Tew DN, Young VK, Dunning JJ, Horsley $\mathrm{J}$, et al. Hyperacute lung rejection in a pig-to-human transplant model. Transplantation 1997;63:594-603.

3. Macchiarini P, Mazmanian GM, Oriol R. Ex-vivo lung model of pig to human hyperacute xenograft rejection. J Thorac Cardiovasc Surg 1997;114:315-25.

4. Daggett CW, Yeatman M, Lodge AJ, Chen EP, Trigt VP, Byrne $\mathrm{GW}$, et al. Swine lungs expressing human complement-regulatory proteins are protected against pulmonary dysfunction in a human plasma perfusion model. J Thorac Cardiovasc Surg 1997; 113:390-8.

5. Hoopes CW, Platt JL. Molecular strategies for clinical xenotransplantation in cardiothoracic surgery. Semin Thorac Cardiovasc Surg 1996;8:156-74.

6. Platt JL, Fischel RJ, Matas AJ, Reif SA, Bolman RM, Bach FH. Immunopathology of hyperacute xenograft rejection in a swineto-primate model. Transplantation 1991;52:214-20.

7. Daggett CW, Yeatman M, Lodge AJ, Chen EP, Linn SS, Gullotto $\mathrm{C}$, et al. Total respiratory support from swine lungs in primate recipients. J Thorac Cardiovasc Surg 1998;115:19-27.

8. Pierson RN, Pino-Chavez G, Young VK, Kaspar-Konig W, White DK, Wallwork J. Expression of human decay accelerating factor may protect pig lung from hyperacute rejection by human blood. J Heart Lung Tranplant 1997;16:231-9.

9. Pierson RN 3d, Kaspar-König W, Tew DN, Young VK, Braidley PC, White DJ, et al. Profound pulmonary hypertension characteristic of pig lung rejection by blood is mediated by xenoreactive antibodies independent of complement. Transplant Proc 1995;27: 274.

10. Macchiarini P, Oriol R, Mazmanian M, Dartevelle P. Lung xenotransplantation: lessons learned and future perspectives. In: Franco KL, Putman JB. Advances in thoracic surgery. Hamilton, Ontario: BC Decker; 1998. p. 404-14.

11. Korchagina EY, Bovin NV. [Synthesis of spacered trisaccharides with blood group specificities A and B, their fragments and structural analogs.] Bioorg Khim 1992;18:283-98.

12. Bovin N, Korchagina E, Zemlyanukhina T, Byramova N, Galanina O, Zemlyakov A, et al. Synthesis of polymeric neoglycoconjugates based on $N$-substituted polyacrylamide. Glycoconjugate J 1993;10:142-51.

13. Bovin NV. Sugar-polyacrylamide conjugates as probes for cell lectins. In: Gabius HJ, Gabius S. Lectins and glycobiology. Berlin: Springer-Verlag; 1993. p. 23-31.

14. Galili U. Interaction of the natural anti-Gal antibody with $\alpha$ galactosyl epitopes: a major obstacle for xenotransplantation. Immunol Today 1993;14:480-2.

15. Rieben R, van Allmen E, Korchagina EY, Nydegger UE, Neethling FA, Kujundzic M, et al. Detection, immunoabsorption, and inhibition of cytotoxic activity of anti- $\alpha \mathrm{Gal}$ antibodies using newly developed substances with synthetic Gal $\alpha 1-3 \mathrm{Gal}$ disaccharide epitopes. Xenotransplantation 1995;2:98-106.

16. Azimzadeh A, Wolf K, Thibaudeau D, Cinqualbre J, Soulillou JP, Anegon I. Comparative study of target antigens for primate xenoreactive natural antibodies in pig and rat endothelial cells. Transplantation 1997;64:1166-74.

17. Sandrin MS, Vaughan HA, Dabrowski PL, McKenzie IF. Anti-pig antibodies in human serum react predominantly with $\mathrm{Gal} \alpha(1,3) \mathrm{Gal}$ epitopes. Proc Natl Acad Sci U S A 1993;90:11391-5.

18. Good AH, Cooper DK, Malcolm AJ, Ippolito E, Koren E, Neethling FA, et al. Identification of carbohydrate structures that bind human anti-porcine antibodies: implications for discordant xenografting in humans. Transplant Proc 1992;24:559-62.

19. Oriol R, Ye Y, Koren E, Cooper DK. Carbohydrate antigens of pig tissues reacting with human natural antibodies as potential targets for hyperacute vascular rejection in pig-to-man organ xenotransplantation. Transplantation 1993;56:1433-42. 
20. Parker W, Bruno D, Holzknecht ZE, Platt JL. Characterization and affinity isolation of xenoreactive human natural antibodies. $\mathrm{J}$ Immunol 1994;153:3791-803.

21. Alexandre GP, Gianello P, Latinne D, Carlier M, Dewalle A, Von Obbergh L, et al. Plasmapheresis and splenectomy in experimental renal xenotransplantation. In: Hardy MA, editor. Xenografts 25. New York. Elsevier Science; 1989. p. 259-66.

22. Palmer A, Welsh K, Gjorstrup P, Bewick M, Thick M. Removal of anti-HLA antibodies by extracorporeal immunoabsorption to enable renal transplantation. Lancet 1989;1:10-2.

23. Cotterell AH, Collins BH, Parker W, Harland RC, Platt JL. The humoral immune response in humans following cross-perfusion of porcine organs. Transplantation 1995;60:861-8.

24. Chari RS, Collins BH, Mages JC, DiMaio JC, Kirk AD, Harland $\mathrm{RC}$, et al. Brief report: treatment of hepatic failure with ex vivo pig-liver perfusion followed by liver transplantation. $\mathrm{N}$ Engl $\mathrm{J}$ Med 1994;331:234-7.

25. Azimzadeh A, Meyer C, Waiter H, Beller JP, Chenard-Neu MP, Kieny R, et al. Removal of primate xenoreactive natural antibodies by extracorporeal perfusion of pig kidneys and livers. Transplant Immunol 1998;6:13-22.

26. Rydberg L, Bjorck S, Hallberg E, Magnusson S, Sumitran S, Samuelsson BE, et al. Extracorporeal ("ex vivo") connection of pig kidneys to humans. II. The anti-pig antibody response. Xenotransplantation 1996;3:340-53.

27. Xu Y, Sablinski T, Gianello P, Bailin M, Monroy R, Kozlowski T, et al. Removal of anti-porcine natural antibodies from human and nonhuman primate plasma in vitro and in vivo by Gal $\alpha 1-3 \mathrm{Gal} \beta 1$ 4ßGlc-X immunoaffinity column. Transplantation 1998;65:172-9.

28. Welsh KI, Taube DH, Thick M, Palmer A, Stevens N, Binns RM. Human antibodies to pig determinants and their association with hyperacute rejection of xenografts. In: Cooper DK, Kemp E, Reemtsma K, White DJ. Xenotransplantation. Berlin: Springer; 1991. p. 501-10.

29. Cooke SP, Hederer J, Pearson D, Savage CO. Characterization of human IgG-binding xenoantigens expressed by porcine aortic endothelial cells. Transplantation 1995;60:1274-84.

30. Atia N, Camoin L, Duflos G, Chereau C, Malassagne B, Filipponi F, et al. Porcine serotransferrin: a major xenoantigen recognized by human natural IgG. Proceedings of the 4th International Congress for Xenotransplantation. Nantes. 1997, abstract 076 .

\section{Discussion}

Dr David J. Sugarbaker (Boston, Mass). It appears as though you have indeed moderated the hyperacute response. To what extent is this simply a washout of the immunologic factors that are responsible for that response? In other words, are you not with your preperfusion simply washing out, to a certain degree, complement and other elements that are the principal components of the hyperacute response?

Dr Macchiarini. I can only speculate, but I think that the reason that the lung acts as an effective protection is simply that xenoactive antibodies are fixed on the lung surface and therefore do not activate the complement after the ex vivo reperfusion. So far, the only recognized antibodies are the anti- $\alpha-G a l$ antibodies. We were able to demonstrate that there are other antibodies, but I do not at this stage know exactly what these other types of antibodies are.

Dr Axel Haverich (Hannover, Germany). I congratulate you on this presentation and elegant study. It may be of significant importance to follow up on these experiments in terms of potential future developments in transgenic or knockout preparations for xenotransplantation. My question is whether you are able to identify-not only detect, but also identify - other antigens or genes related to the xenoreactive antibody response in human beings.

Also, do you not think that for further experiments it would be important to change the model in terms of the pig to primate model so that you would also be able to look at the delayed xenoresponse and cellular rejection?

Dr Macchiarini. In response to the first question, yes we can. There is a simple method, but we need to go back and remake the ex vivo lung perfusion. You do the same experiments, but you have to lyophilize lungs to see what kind of antibodies were fixed on the lung and eliminate them from the other population of potential xenoantibodies present in the circulation. We are currently planning to do that.

With respect to the second question, such a change indeed would be great; however, there is an economic problem because nonhuman primates are expensive, and I think that the lung as opposed to the heart is at the early stage of this type of investigation. As you know better than I, with a transgenic pig you can afford partial protection from hyperacute rejection, but it still takes place after a few days if you use a transgenic pig for complement regulatory proteins.

Dr Chris T. Salerno (Minneapolis, Minn). There has been some suggestion that in lung xenotransplantation the associated increase in PVR produces some endothelial cell damage that leads to activation of the alternative complement pathway. Did you look at all at activation of the alternative complement pathway?

Dr Macchiarini. Not in this study, but in a previous study we demonstrated that the first pathway of the complement activation is classic. You may have alternative pathways in the lung - not in the pig to human models but, for instance, in the rat to human models. 